\title{
Pengaruh pupuk pelengkap cair dan sistem olah tanah terhadap pertumbuhan dan hasil kacang tanah (Arachis hypogaea L.) kultivar kancil pada inceptisols Jatinangor
}

\section{The effect of liquid organic fertilizer and soil tillage system on growth and yield of peanut (Arachis hypogaea L.) cultivar kancil on inceptisols Jatinangor}

Diterima : 15 November 2016/Disetujui : 15 Desember 2016 / Dipublikasikan : 30 Desember 2016

CDepartment of Crop Science, Padjadjaran University

\begin{abstract}
The objective of this experiment was to study the effect of liquid organic dosage and on growth and soil tillage system yield of peanut (Arachis hypogaea L.) on Inceptisols Jatinangor. The experiment was carried out from January 2015 until April 2015 at the research station of Agriculture, Faculty of Padjadjaran University, Jatinangor. The experimental design was used a Randomized Block Design (RBD) consist of eighteen treatments and replicatied two times. The treatments were : Control $(50 \mathrm{~kg} / \mathrm{ha}$ Urea +125 $\mathrm{kg} / \mathrm{ha} \mathrm{SP}-36$ + $100 \mathrm{~kg} / \mathrm{ha} \mathrm{KC1}$ ) + zero tillage, Control $(50 \mathrm{~kg} / \mathrm{ha}$ Urea $+125 \mathrm{~kg} / \mathrm{ha}$ SP-36 + 100 $\mathrm{kg} / \mathrm{ha}$ KC1) + minimum tillage, Control $(50 \mathrm{~kg} / \mathrm{ha}$ Urea $+125 \mathrm{~kg} / \mathrm{ha} \mathrm{SP}-36+100 \mathrm{~kg} / \mathrm{ha} \mathrm{KC1)}+$ full tillage, $(1 \mathrm{~L} /$ ha $\mathrm{LOF}+$ zero tillage, $1 \mathrm{~L} / \mathrm{ha} \mathrm{LOF}+$ minimum tillage, $1 \mathrm{~L} /$ ha LOF + full tillage, $2 \mathrm{~L} /$ ha $\mathrm{LOF}+2 \mathrm{~L} / \mathrm{ha} \mathrm{LOF}+$ minimum tillage, $2 \mathrm{~L} / \mathrm{ha} \mathrm{LOF}$ + full tillage, $3 \mathrm{~L} / \mathrm{ha} \mathrm{LOF}+$ zero tillage, $3 \mathrm{~L} / \mathrm{ha}$ $\mathrm{LOF}+$ minimum tillage, $3 \mathrm{~L} / \mathrm{ha} \mathrm{LOF}+$ full tillage, $4 \mathrm{~L} /$ ha LOF + zero tillage, $4 \mathrm{~L} / \mathrm{ha} \mathrm{LOF}+$ minimum tillage, $4 \mathrm{~L} / \mathrm{ha} \mathrm{LOF}+$ full tillage, $5 \mathrm{~L} / \mathrm{ha} \mathrm{LOF}+$ zero tillage, $5 \mathrm{~L} / \mathrm{ha} \mathrm{LOF}+$ minimum tillage, 5 $\mathrm{L} /$ ha LOF + full tillage. Scott-knott test was used to analyze the average of the treatments.

The result of experiment showed that there were significant effect of liquid organic fertilizer dosage and soil tillage system on leaf area index, dry weight of plant, number of seed per plant, number of filled pod per plant, weight of 100 seeds, seed weight per plant and seed weight per plot. The treatment of $5 \mathrm{~L} / \mathrm{ha} \mathrm{LOF}+$ minimum tillage gives better effect on leaf area index, dry weight of plant, number of seed per plant, number of filled pod per
\end{abstract}

\footnotetext{
Dikomunikasikan oleh Agus Wahyudin

Irwan, A.W. · F. Y. Wicaksono

Staff Pengajar Departemen Budidaya Pertanian, Fakultas

Pertanian, Universitas Padadjaran

Jl. Raya Bandung-Sumedang Km 21, Jatinangor Sumedang
}

plant, weight of 100 seeds, seed weight per plant and seed weight per plot than other treatment which used of liquid organic fertilizer dosage and was not different with the treatments Control 50 $\mathrm{kg} / \mathrm{ha}$ Urea $+125 \mathrm{~kg} / \mathrm{ha}+\mathrm{SP}-36+100 \mathrm{~kg} / \mathrm{ha} \mathrm{KC1}$ + full and $5 \mathrm{~L} / \mathrm{ha} \mathrm{LOF}+$ full tillage.

Keywords : Peanut - Liquid organic fertilizer . Soil tillage system

Sari Percobaan ini bertujuan untuk mengetahui pengaruh dosis pupuk pelengkap organik cair dan sistem olah tanah terhadap pertumbuhan dan hasil kacang tanah (Arachis hypogaea L.). Percobaan dilaksanakan di Kebun Percobaan Fakultas Pertanian, Universitas Padjadjaran, Jatinangor, dari bulan Januari 2015 sampai April 2015. Rancangan percobaan yang digunakan adalah rancangan acak kelompok (RAK) dengan 18 perlakuan dan 2 ulangan. Perlakuannya meliputi : kontrol $(50 \mathrm{~kg} / \mathrm{ha}$ Urea $+125 \mathrm{~kg} / \mathrm{ha}$ SP-36 + 100 $\mathrm{kg} / \mathrm{ha} \mathrm{KC1)} \mathrm{+} \mathrm{tanpa} \mathrm{olah} \mathrm{tanah,} \mathrm{kontrol} \mathrm{(50} \mathrm{kg/ha}$ Urea + $125 \mathrm{~kg} / \mathrm{ha}$ SP-36 + $100 \mathrm{~kg} / \mathrm{ha}$ KC1) + pengolahan tanah minimum, kontrol $(50 \mathrm{~kg} / \mathrm{ha}$ Urea + $125 \mathrm{~kg} / \mathrm{ha}$ SP-36 + $100 \mathrm{~kg} / \mathrm{ha} \mathrm{KC1)} \mathrm{+}$ pengolahan tanah sempurna, $1 \mathrm{~L} / \mathrm{ha}$ PPC + tanpa olah tanah, $1 \mathrm{~L} /$ ha PPC + pengolahan tanah minimum, $1 \mathrm{~L} /$ ha PPC + pengolahan tanah sempurna, $2 \mathrm{~L} /$ ha PPC + Tanpa olah tanah, $2 \mathrm{~L} / \mathrm{ha}$ PPC + pengolahan tanah minimum, $2 \mathrm{~L} / \mathrm{ha} \mathrm{PPC}+$ pengolahan tanah sempurna, $3 \mathrm{~L} / \mathrm{ha} \mathrm{PPC}+$ tanpa olah tanah, $3 \mathrm{~L} /$ ha PPC + pengolahan tanah minimum, $3 \mathrm{~L} / \mathrm{ha} \mathrm{PPC}+$ pengolahan tanah sempurna, $4 \mathrm{~L} /$ ha PPC + tanpa olah tanah, $4 \mathrm{~L} /$ ha $\mathrm{PPC}+$ pengolahan tanah minimum, $4 \mathrm{~L} / \mathrm{ha} \mathrm{PPC}+$ pengolahan tanah sempurna, $5 \mathrm{~L} / \mathrm{ha} \mathrm{PPC}+$ tanpa olah tanah, $5 \mathrm{~L} /$ ha PPC + pengolahan tanah minimum, $5 \mathrm{~L} / \mathrm{ha} \mathrm{PPC}+$ pengolahan tanah sempurna. Nilai rata-rata tiap perlakuan diuji 
dengan menggunakan uji Scott-knott. Hasil percobaan menunjukkan bahwa dosis pupuk pelengkap cair dan sistem olah tanah berpengaruh terhadap indeks luas daun, bobot kering tanaman, jumlah biji per tanaman, jumlah polong isi per tanaman, bobot 100 biji, bobot biji per tanaman dan bobot biji per petak. Perlakuan 5 L/ha PPC + pengolahan tanah minimum memberikan pengaruh terhadap indeks luas daun, bobot kering tanaman, jumlah biji per tanaman, jumlah polong isi per tanaman, bobot 100 biji, bobot biji per tanaman dan bobot biji per petak dibanding dengan perlakuan yang menggunakan pupuk pelengkap cair dan tidak berbeda dengan perlakuan kontrol $50 \mathrm{~kg} / \mathrm{ha}$ Urea + $125 \mathrm{~kg} / \mathrm{ha}$ SP$36+100 \mathrm{~kg} / \mathrm{ha} \mathrm{KCl}+$ pengolahan tanah sempurna dan $5 \mathrm{~L} /$ ha PPC + pengolahan tanah sempurna.

Kata kunci : Kacang tanah - Pupuk organik cair . Sistem olah tanah

\section{Pendahuluan}

Di negara Indonesia, komoditas kacang tanah (Arachis hypogaea L.) merupakan komoditas unggulan kedua setelah kedelai yang dikembangkan sebagai komoditas pangan dan industri olah makanan. Permintaan pasar semakin meningkat seiring dengan penggunaan kacang tanah sebagai komoditas pangan. Usaha tani kacang tanah relatif lebih efisien dibandingkan kedelai (Manwan dkk., 1990). Hal ini karena pemeliharaannya lebih mudah, penggunaan pupuk lebih sedikit, hama utamanya lebih sedikit dibandingkan dengan kedelai, namun kacang tanah relatif peka terhadap pengolahan tanah karena polongnya berada di dalam tanah. Semakin baik pengolahan tanah, maka hasilnya semakin tinggi (Astanto, dkk. 1999).

Tanaman kacang tanah merupakan tanaman penghasil lemak nabati, protein, mineral, kalsium, fosfor, besi, dan vitamin A serta asam-asam amino, dan sebagai pangan, pakan ternak, dan bahan minyak goreng nabati. Produksi kacang tanah di Indonesia mengalami perubahan dari tahun ke tahun, sejalan dengan permintaan pasar domestik yang selalu berubah.

Pada tahun 2015 luas panen kacang tanah di Indonesia sebesar 454.349 ha, produksinya sebesar 605.449 ton, dan produktivitasnya sebesar $13.33 \mathrm{ku} / \mathrm{ha}$ (BPS, 2016)

Dalam memenuhi kekurangan pengadaan dalam negeri setiap tahunnya dalam lima tahun terakhir ini, maka kekurangan tersebut dapat dipenuhi dengan mengimpor dari negara lain. Jumlah impor ini terus bertambah karena adanya peningkatan kebutuhan dalam negeri yang terus meningkat.

Produktivitas kacang tanah yang masih rendah ini dapat disebabkan oleh beberapa faktor, antara lain masih sederhananya teknik budidaya yang dilakukan petani dan terdapatnya kendala produksi, seperti tingkat kesuburan lahan yang relatif rendah, cekaman kekeringan (kekurangan air), serta belum banyaknya petani menggunakan kultivar unggul (Arsyad dkk., 1993). Salah satu kultivar unggul adalah kultivar Kancil yang toleran terhadap kekeringan dan relatif tahan terhadap tanah yang padat (Pusat Penelitian dan Pengembangan Tanaman Pangan, 1999).

Salah satu usaha yang dapat dilakukan untuk meningkatkan hasil persatuan luas, yaitu dengan perbaikan teknik budidaya. Teknik budidaya tersebut adalah perbaikan teknik pengolahan lahan dan pemupukan yang tepat. Baik untuk pupuk organik maupun anorganik sehingga unsur hara bagi tanaman akan tersedia (Sri Setyati Haryadi, 1989).

Sampai saat ini teknik budidaya yang diterapkan, masih menggunakan pengolahan tanah secara konvensional. Dengan adanya pengolahan tanah yang baik diharapkan dapat meningkatkan besarnya aerasi, pertumbuhan gulma menurun dan meningkatkan produksi, sehingga ketersediaan unsur hara meningkat bagi pertumbuhan tanaman dan berproduksi dengan baik (Naik Sinukaban, 1981).

Pemupukan merupakan salah satu usaha pemberian unsur-unsur hara yang dibutuhkan oleh tanaman untuk menambah persediaan unsur hara di dalam tanah. Pada umumnya pemupukan dilakukan melalui akar, tetapi pemberian melalui daun dan batang juga dapat dilakukan dalam bentuk larutan (Sri Setyati Haryadi, 1989). Unsur-unsur hara dapat diberikan melalui tanah walaupun tidak diserap seluruhnya oleh tanaman sehingga hasil yang didapatkan terasa kurang menguntungkan, namun penyerapannya akan lebih baik bila ditunjang dengan kesuburan fisik dan kimia yang baik. Khusus untuk unsur hara mikro, jumlah pemupukannya sedikit namun ketersediaanya harus terpenuhi, tidak dapat digantikan dengan unsur hara yang lain (mikro esensial).

Penelitian tentang pengaruh dosis pupuk pelengkap cair dan sistem olah tanah terhadap pertumbuhan dan hasil kacang tanah belum 
banyak dilakukan, sehingga perlu dilakukan penelitian untuk mengetahui pengaruhnya.

Penelitian ini bertujuan untuk mengetahui pengaruh dosis pupuk pelengkap cair dan sistem olah tanah terhadap pertumbuhan dan hasil kacang tanah (Arachis hypogaea L.). pada tanah Inceptisol Jatinangor. Penelitian ini diharapkan dapat memberikan informasi yang bermanfaat bagi petani maupun pengusaha di bidang pangan, khususnya kacang tanah sehingga dapat meningkatkan produktivitasnya.

\section{Bahan dan Metode}

Penelitian ini dilaksanakan di Kebun Percobaan Fakultas Pertanian Universitas Padjadjaran Jatinangor Kabupaten Sumedang, Jawa Barat, ketinggian tempat sekitar $750 \mathrm{~m} \mathrm{dpl}$, dengan tipe $C_{3}$ menurut klasifikasi Oldeman (1975). Jenis tanah inceptisol dengan $\mathrm{pH}$ tanah 5,6 (masam) dari bulan Januari 2015 sampai dengan April 2015.

Benih kacang tanah yang ditanam adalah kultivar Kancil berasal dari BALITKABI Malang, Jawa Timur, hasil panen Desember 2014, umur panen 90 hari setelah tanam, bobot 100 biji 40 50 gram. Pupuk yang digunakan terdiri atas pupuk dasar (Urea, SP-36 dan $\mathrm{KCl}$ ), dan pupuk pelengkap cair (PPC) yang digunakan adalah BIOREG (merk dagang), mengandung $0.18 \%$ Amina dan Unsur mikro lengkap $0.36 \%$.

Pemberian pupuk dasar sebagai kontrol dilakukan dengan cara ditugal, sedangkan pemberian pupuk pelengkap cair dilakukan dengan cara menyiramkannya ke tanah sekitar perakaran, waktu aplikasi 2, 4, dan 6 MST.

Ukuran petak percobaan $3 \times 2 \mathrm{~m}^{2}$, pengolahan tanah terdiri atas tanpa olah tanah, dimana tanah tidak diolah sama sekali, untuk membersihkan gulma dilakukan penyemprotan herbisida Round Up $3 \mathrm{ml} / 1$ seminggu sebelum tanam; pengolahan tanah minimum dilakukan terhadap tanah yang diolah hanya pada barisan tanaman dengan lebar $20 \mathrm{~cm}$ dengan pengolahan tanah hanya dilakukan satu kali, dan pengolahan tanah sempurna yaitu tanah diolah seluruhnya sampai tanah menjadi gembur, dilakukan dua kali yaitu seminggu sebelum tanam dan sehari sebelum tanam. Jarak tanam yang digunakan untuk penanaman kacang tanah yaitu $25 \mathrm{~cm} \times 25 \mathrm{~cm}$.

Rancangan percobaan menggunakan Rancangan Acak Kelompok yang terdiri dari 18 perlakuan diulang $2 \mathrm{kali}$, setiap petak terdiri dari 100 tanaman. Adapun perlakuannya adalah : A = Kontrol ( $50 \mathrm{~kg} / \mathrm{ha}$ Urea $+125 \mathrm{~kg} / \mathrm{ha}$ SP-36 + $100 \mathrm{~kg} / \mathrm{ha} \mathrm{KC} 1)+$ Tanpa olah tanah, B = Kontrol $(50 \mathrm{~kg} / \mathrm{ha}$ Urea $+125 \mathrm{~kg} / \mathrm{ha}$ SP-36 +100 $\mathrm{kg} / \mathrm{ha}$ KC1) + Pengolahan tanah minimum, $\mathrm{C}=$ Kontrol ( $50 \mathrm{~kg} / \mathrm{ha}$ Urea $+125 \mathrm{~kg} / \mathrm{ha}$ SP-36 + 100 $\mathrm{kg} / \mathrm{ha} \mathrm{KC} 1)+$ Pengolahan tanah sempurna, $\mathrm{D}=$ $1 \mathrm{~L} /$ ha PPC + Tanpa olah tanah, E $=1 \mathrm{~L} /$ ha PPC + Pengolahan tanah minimum, $\mathrm{F}=1 \mathrm{~L} / \mathrm{ha} \mathrm{PPC}$ + Pengolahan tanah sempurna, $\mathrm{G}=2 \mathrm{~L} / \mathrm{ha}$ PPC + Tanpa olah tanah, $\mathrm{H}=2 \mathrm{~L} / \mathrm{ha} \mathrm{PPC}+$ Pengolahan tanah minimum, $\mathrm{I}=2 \mathrm{~L} / \mathrm{ha} \mathrm{PPC}+$ Pengolahan tanah sempurna, $\mathrm{J}=3 \mathrm{~L} / \mathrm{ha} \mathrm{PPC}+$ Tanpa olah tanah, $\mathrm{K}=3 \mathrm{~L} /$ ha PPC + Pengolahan tanah minimum, $\mathrm{L}=3 \mathrm{~L} /$ ha $\mathrm{PPC}+$ Pengolahan tanah sempurna, $\mathrm{M}=4 \mathrm{~L} / \mathrm{ha} \mathrm{PPC}+$ Tanpa olah tanah, $\mathrm{N}=4 \mathrm{~L} /$ ha PPC + Pengolahan tanah minimum, $\mathrm{O}=4 \mathrm{~L} /$ ha $\mathrm{PPC}+$ Pengolahan tanah sempurna, $\mathrm{P}=5 \mathrm{~L} /$ ha PPC + Tanpa olah tanah, $\mathrm{Q}=5 \mathrm{~L} /$ ha PPC + Pengolahan tanah minimum, $\mathrm{R}=5 \mathrm{~L} /$ ha PPC + Pengolahan tanah sempurna. Nilai rata-rata tiap perlakuan diuji dengan menggunakan uji Scott-knott.

Pengamatan dilakukan terhadap jumlah bintil akar dan bobot kering bintil akar, hama dan penyakit tanaman serta analisis tanah awal sebagai pengamatan penunjang, sedangkan tinggi tanaman, indeks luas daun, bobot kering tanaman, jumlah biji pertanaman, jumlah polong isi pertanaman, jumolah polong hampa pertanaman (cipo), jumlah ginofor, bobot 100 butir, bobot biji pertanaman dan bobot biji per petak sebagai pengamatan utama.

\section{Hasil dan Pembahasan}

Jumlah bintil akar dan bobot kering bintil akar. Jumlah bintil akar dan bobot kering akar terbaik terdapat pada perlakuan kontrol 50 $\mathrm{kg} / \mathrm{ha}$ Urea $+125 \mathrm{~kg} / \mathrm{ha}$ SP-36 + $100 \mathrm{~kg} / \mathrm{ha} \mathrm{KCl}$ + pengolahan tanah sempurna menghasilkan 36,88 bintil akar dan 0,952 gram. Hal ini disebabkan kandungan unsur $\mathrm{N}$ yang diberikan ke dalam tanah perlakuan kontrol cukup sebagai starter untuk proses infeksi Rhizobium terhadap akar (Poehlman, 1991). Pengolahan tanah sempurna membuat struktur tanah menjadi gembur sehingga perkembangan akar menjadi baik. Hal ini memperbesar infeksi bakteri Rhizobium terhadap akar sehingga jumlah bintil akar lebih banyak.

Organisme Pengganggu dan Lingkungan Tumbuh. Hama yang menyerang tanaman, yaitu belalang (Valanga nigricornis). Belalang menyerang 
tanaman terutama saat tanaman masih muda sehingga nengakibatkan daun menjadi robek dan berlubang, tetapi percobaan di lapangan mnenunjukkan tingkat serangan belalang tidak sampai menimbulkan kerusakan yang signifikan, sekitar 5-10\%. Pengendalian dengan melakukan penyemprotan Curacron 500 EC dengan konsentrasi $2 \mathrm{ml} / 1$ air (saat terjadi serangan) yaitu pada 5 mst dan 8 mst (fase kritis).

Jenis penyakit yang menyerang adalah bercak daun (Cercospora rachidicola). Gejala serangannya yaitu permukaan atas maupun bawah daun berwarna coklat. Tanaman yang terserang penyakit sebesar $2 \%$ dan dapat diatasi dengan penyemprotan Dithane M-45 dengan konsentrasi $2 \mathrm{~g} / \mathrm{L}$ (4 mst sampai 12 mst dengan interval waktu satu minggu sekali).

Gulma yang tumbuh dominan pada lahan tempat percobaan yaitu teki (Cypenis rotundus), putri malu (Mimosa pudica), dan kakawatan (Cynodon dactilon). Pengendalian gulma dipakai herbisida Round Up $3 \mathrm{ml} / 1$.

Berdasarkan hasil analisis tanah diketahui bahwa jenis tanah tempat percobaan termasuk jenis tanah inceptisols. Tanah tersebut memiliki tekstur liat berdebu dengan komposisi $16 \%$ pasir, $40 \%$ debu, dan $44 \%$ liat. Nilai $\mathrm{pH}$ yang terukur dari tanah tersebut adalah 5.6 (masam), pH yang baik untuk pertumbuhan kacang tanah adalah $6-6,5$ (Sutarto, dkk., 1988). Berdasarkan perbandingan kadar C - organik (2.94\%) dan N - total (0.25\%), tanah tersebut memiliki nilai $\mathrm{C} / \mathrm{N}$ ratio sebesar 13 termasuk kriteria sedang, hal ini menunjukan bahwa tingkat dekomposisi bahan organik dalam tanah tersebut barada pada tingkatan sedang. Tanah tempat percobaan memiliki kandungan $\mathrm{P}_{2} \mathrm{O}_{5}$ tersedia (Bray) 9.2 ppm (rendah), $\mathrm{P}_{2} \mathrm{O}_{5}$ total (HC1) $22.4 \mathrm{mg} / 100 \mathrm{~g}$ (sedang), dan $\mathrm{K}_{2} \mathrm{O}$ (HC1) $20.1 \mathrm{mg} / 100$ $\mathrm{g}$ (sedang), kapasitas tukar kation $18.2 \mathrm{me} / 100 \mathrm{~g}$ (sedang), kejenuhan basa 47 \% (rendah).

Data curah hujan selama penelitian berlangsung menunjukan bahwa curah hujan (bulan Januari 2015 - April 2015) rata-rata pada bulan Januari $220.5 \mathrm{~mm}$ karena masih ada hujan, bulan Februari $125.8 \mathrm{~mm}$ dengan jumlah hari hujan 18 hari, bulan Maret $95.6 \mathrm{~mm}$ dengan jumlah hari hujan 6 hari, bulan April 46,7 mm dengan jumlah curah hujan 2 hari. Jumlah curah hujan ini relatif sesuai untuk tanaman kacang tanah yaitu 45 - 200 mm/bulan (Sutarto dkk., 1988), untuk memenuhi kebutuhan air selama tidak turun hujan maka dilakukan penyiraman dengan interval waktu 2 kali sehari selama pertumbuhan vegetatif sampai memasuki fase reproduktif (fase pengisian biji).
Tinggi Tanaman. Berdasarkan analisis data tinggi tanaman pada umur 6 minggu setelah tanam (mst) dan 8 mst (Tabel 1), pupuk organik cair dan sistem olah tanah tidak memberikan pengaruh terhadap tinggi tanaman. Hal ini diduga pada umur tersebut mulai terjadi pembentukan polong, fotosintat banyak ditranslokasikan ke organ generatif tanaman sehingga pertumbuhan batangnya relatif seragam.

Tabel 1. Pengaruh Pupuk Pelengkap Cair dan Sistem Olah Tanah Terhadap Tinggi Tanaman.

\begin{tabular}{ccc}
\hline \multirow{2}{*}{ Perlakuan } & \multicolumn{2}{c}{ Rata-rata tinggi tanaman $(\mathrm{cm})$} \\
\cline { 2 - 3 } & $6 \mathrm{mst}$ & $8 \mathrm{mst}$ \\
\hline $\mathrm{A}$ & $12,57 \mathrm{a}$ & $14,27 \mathrm{a}$ \\
$\mathrm{B}$ & $12,75 \mathrm{a}$ & $14,33 \mathrm{a}$ \\
$\mathrm{C}$ & $13,60 \mathrm{a}$ & $16,81 \mathrm{a}$ \\
$\mathrm{D}$ & $11,62 \mathrm{a}$ & $14,92 \mathrm{a}$ \\
$\mathrm{E}$ & $11,43 \mathrm{a}$ & $14,22 \mathrm{a}$ \\
$\mathrm{F}$ & $12,08 \mathrm{a}$ & $14,36 \mathrm{a}$ \\
$\mathrm{G}$ & $12,02 \mathrm{a}$ & $14,52 \mathrm{a}$ \\
$\mathrm{H}$ & $13,30 \mathrm{a}$ & $15,84 \mathrm{a}$ \\
$\mathrm{I}$ & $13,13 \mathrm{a}$ & $15,67 \mathrm{a}$ \\
$\mathrm{J}$ & $12,07 \mathrm{a}$ & $14,41 \mathrm{a}$ \\
$\mathrm{K}$ & $13,73 \mathrm{a}$ & $15,22 \mathrm{a}$ \\
$\mathrm{L}$ & $14,30 \mathrm{a}$ & $15,12 \mathrm{a}$ \\
M & $13,10 \mathrm{a}$ & $14,47 \mathrm{a}$ \\
$\mathrm{N}$ & $13,87 \mathrm{a}$ & $16,67 \mathrm{a}$ \\
O & $14,53 \mathrm{a}$ & $15,73 \mathrm{a}$ \\
P & $12,90 \mathrm{a}$ & $14,40 \mathrm{a}$ \\
Q & $13,65 \mathrm{a}$ & $15,12 \mathrm{a}$ \\
R & $12,94 \mathrm{a}$ & $16,65 \mathrm{a}$ \\
\hline \hline
\end{tabular}

Keterangan : Nilai rata-rata perlakuan yang ditandai huruf yang sama pada kolom yang sama menunjukkan tidak berbeda nyata menurut Metode Analisis Scott-Knott pada taraf $5 \%$.

Indeks Luas Daun dan Bobot Kering Tanaman. Hasil analisis data indeks luas daun per tanaman dapat dilihat pada Tabel 2 . Perlakuan dosis pupuk organik cair dan sistem olah tanah berpengaruh terhadap indeks luas daun.

Pada Tabel 2 terlihat bahwa perlakuan B Kontrol (50 kg/ha Urea + $125 \mathrm{~kg} /$ ha SP-36 + 100 $\mathrm{kg} / \mathrm{ha} \mathrm{KC} 1)+$ pengolahan tanah minimum, $\mathrm{C}$ Kontrol (50 kg/ha Urea + $125 \mathrm{~kg} /$ ha SP-36 + 100 $\mathrm{kg} / \mathrm{ha} \mathrm{KC1}$ ) + pengolahan tanah maksimuni, L (3 L/ha PPC + pengolahan tanah sempurna), Q (5 L/ha $\mathrm{PPC}+$ pengolahan tanah minimum), dan R (5 L/ha PPC + pengolahan tanah sempurna) berbeda dengan perlakuan lainnya. Pengolahan tanah sempurna dan minimum menghasilkan indeks luas daun yang lebih baik dibandingkan perlakuan tanpa olah tanah, 
menciptakan struktur tanah yang lebih gembur, aerasi dan drainase yang lebih baik dibandingkan tanpa olah tanah, sehingga pertumbuhan akar lebih optimal. Jika pertumbuhan akar baik maka penyerapan air untuk fotosintesis lebih optimal sehingga hasil fotosintat untuk pertumbuhan daun lebih banyak.

Pertumbuhan daun yang baik dapat dilihat dari indeks luas daun yang besar. Menurut Gardner dkk., (1991), semakin luas daun maka akan semakin banyak jumlah klorofil yang dapat melakukan proses fotosintesis, sehingga fotosintat yang dihasilkan akan semakin banyak untuk selanjutnya disalurkan ke bagian tanaman yang membutuhkan seperti akar, batang, dan juga daun yang terakumulasi dalam ruang sel tanaman. Fotosintat yang dihasilkan dari proses fotosintesis akan ditranslokasikan ke seluruh organ tanaman yang membutuhkan, sehingga dapat merangsang pembesaran ukuran sel serta meningkatkan pembelahan sel, akibatnya dapat menyebabkan pertambahan panjang dan memperluas permukaan daun (Liliek Agustina, 1990).

Tabel 2. Pengaruh Pupuk Pelengkap Cair dan Sistem Olah Tanah Terhadap Indeks Luas Daun dan Bobot Kering Tanaman.

\begin{tabular}{ccc}
\hline \hline Perlakuan & $\begin{array}{c}\text { Rata-rata } \\
\text { Indeks Luas } \\
\text { Daun }\end{array}$ & $\begin{array}{c}\text { Rata-rata Bobot } \\
\text { KeringTanaman } \\
(\mathrm{g})\end{array}$ \\
\hline $\mathrm{A}$ & $0,34 \mathrm{a}$ & $2,56 \mathrm{a}$ \\
$\mathrm{B}$ & $0,43 \mathrm{~b}$ & $3,34 \mathrm{~b}$ \\
$\mathrm{C}$ & $0,50 \mathrm{~b}$ & $3,94 \mathrm{~b}$ \\
$\mathrm{D}$ & $0,23 \mathrm{a}$ & $1,90 \mathrm{a}$ \\
E & $0,29 \mathrm{a}$ & $1,62 \mathrm{a}$ \\
$\mathrm{F}$ & $0,32 \mathrm{a}$ & $1,83 \mathrm{a}$ \\
$\mathrm{G}$ & $0,25 \mathrm{a}$ & $1,38 \mathrm{a}$ \\
$\mathrm{H}$ & $0,32 \mathrm{a}$ & $2,32 \mathrm{a}$ \\
$\mathrm{I}$ & $0,33 \mathrm{a}$ & $1,80 \mathrm{a}$ \\
$\mathrm{J}$ & $0,27 \mathrm{a}$ & $1,56 \mathrm{a}$ \\
K & $0,30 \mathrm{a}$ & $1,89 \mathrm{a}$ \\
$\mathrm{L}$ & $0,42 \mathrm{a}$ & $2,32 \mathrm{a}$ \\
M & $0,25 \mathrm{a}$ & $1,97 \mathrm{a}$ \\
$\mathrm{N}$ & $0,33 \mathrm{a}$ & $2,51 \mathrm{a}$ \\
O & $0,35 \mathrm{a}$ & $3,42 \mathrm{~b}$ \\
P & $0,27 \mathrm{a}$ & $1,93 \mathrm{a}$ \\
Q & $0,42 \mathrm{~b}$ & $3,22 \mathrm{~b}$ \\
R & $0,43 \mathrm{~b}$ & $3,30 \mathrm{~b}$ \\
\hline \hline
\end{tabular}

Keterangan : Nilai rata-rata perlakuan yang ditandai huruf yang sama pada kolom yang sama menunjukkan tidak berbeda nyata menurut Metode Analisis Scott-Knott pada taraf $5 \%$.

Perlakuan A, D, E, F, G, H, I, J, K, M, N, O, dan $P$ menghasilkan ILD yang lebih rendah. Hal ini disebabkan unsur hara yang tersedia dalam perlakuan tersebut lebih kecil dibandingkan dengan perlakuan lainnya. Menurut Sumarno (1987), pemberian unsur hara melalui pemupukan terhadap tanaman kacang tanah harus dilakukan dengan benar dan tepat, sebab pemupukan yang kurang atau berlebihan dapat menyebabkan produksi kacang tanah menjadi rendah. Pada perlakuan $\mathrm{P}$, meskipun dosis yang diberikan tinggi sistem pengolahan tanah yang dilakukan adalah tanpa olah tanah. Hal ini dapat mempengaruhi proses penyerapan air yang dibutuhkan tanaman dalam proses fosintesis.

Perlakuan dosis pupuk pelengkap cair dan sistem olah tanah berpengaruh terhadap bobot kering tanaman, terlihat bahwa perlakuan B, C, $\mathrm{O}, \mathrm{Q}$ dan $\mathrm{R}$ berbeda dengan perlakuan lainnya. Hal ini terjadi karena pengaruh pengolahan tanah yang dilakukan, dimana pengolahan tanah dapat menciptakan struktur tanah yang gembur, drainase dan aerasi yang baik sehingga penyerapan air dan unsur hara dalam tanah yang tersedia dapat diserap oleh tanaman lebih banyak. Menurut Leiwabessy (1982), unsur hara yang tersedia dalam keadaan seimbang (sesuai kebutuhan tanaman) akan meningkatkan pertumbuhan vegetatif dan bobot kering.

Perlakuan A, D, E, F, G, H, I, J, K, L, M, N dan $P$ menghasilkan bobot kering tanaman lebih rendah. Perlakuan dengan dosis PPC yang sedikit (kurang dari 41 /ha PPC) dan atau dengan sistem olah tanah TOT menghasilkan bobot kering tanaman yang rendah yang mencerminkan banyak sedikitnya akumulasi fotosintat pada fase vegetatif dalam perlakuan tersebut. Perlakuan yang menghasilkan bobot kering tanaman yang rendah dapat disebabkan karena unsur hara yang diberikan kurang mencukupi dan atau karena sistem olah tanah yang digunakan adalah TOT, dimana dengan pengolahan secara TOT mengakibatkan tanah lebih padat pada lapisan olah (Saifuddin Sarief, 1993). Akibat lain dari TOT adalah efisiensi pemupukan terutama $\mathrm{N}$ dengan dosis suboptimal akan lebih rendah, sehingga proses pertumbuhan pada fase vegetatif menjadi terhambat.

Jumlah Biji per Tanaman dan Jumlah Polong Isi per Tanaman. Berdasarkan analisis data, dosis pupuk organik cair dan sistem olah tanah berpengaruh terhadap jumlah biji per tanaman. Tabel 3, menunjukkan bahwa perlakuan $\mathrm{C}, \mathrm{O}, \mathrm{Q}$ dan $\mathrm{R}$ berbeda dengan perlakuan lainnya yaitu memiliki jumlah biji per tanaman yang lebih banyak. 
Tabel 3. Pengaruh Pupuk Pelengkap Cair dan Sistem Olah Tanah Terhadap Jumlah Biji per Tanaman dan Jumlah Polong Isi per Tanaman.

\begin{tabular}{ccc}
\hline \hline Perlakuan & $\begin{array}{c}\text { Jumlah Biji per } \\
\text { Tanaman }\end{array}$ & $\begin{array}{c}\text { Jumlah Polong } \\
\text { Isi per tanaman }\end{array}$ \\
\hline A & $18,28 \mathrm{~b}$ & $14,24 \mathrm{a}$ \\
$\mathrm{B}$ & $19,44 \mathrm{~b}$ & $15,34 \mathrm{a}$ \\
$\mathrm{C}$ & $25,58 \mathrm{~d}$ & $19,17 \mathrm{~b}$ \\
$\mathrm{D}$ & $17,37 \mathrm{a}$ & $13,74 \mathrm{a}$ \\
$\mathrm{E}$ & $19,79 \mathrm{~b}$ & $14,34 \mathrm{a}$ \\
$\mathrm{F}$ & $23,35 \mathrm{c}$ & $15,25 \mathrm{a}$ \\
$\mathrm{G}$ & $16,63 \mathrm{a}$ & $12,43 \mathrm{a}$ \\
$\mathrm{H}$ & $18,32 \mathrm{~b}$ & $14,65 \mathrm{a}$ \\
$\mathrm{I}$ & $20,80 \mathrm{~b}$ & $15,50 \mathrm{a}$ \\
$\mathrm{J}$ & $18,18 \mathrm{a}$ & $13,80 \mathrm{a}$ \\
K & $16,47 \mathrm{a}$ & $15,32 \mathrm{a}$ \\
$\mathrm{L}$ & $22,33 \mathrm{c}$ & $15,15 \mathrm{a}$ \\
M & $19,56 \mathrm{~b}$ & $14,42 \mathrm{a}$ \\
$\mathrm{N}$ & $21,44 \mathrm{c}$ & $16,63 \mathrm{~b}$ \\
$\mathrm{O}$ & $24,20 \mathrm{~d}$ & $16,70 \mathrm{~b}$ \\
P & $18,47 \mathrm{~b}$ & $11,35 \mathrm{a}$ \\
Q & $24,74 \mathrm{~d}$ & $16,56 \mathrm{~b}$ \\
R & $25,59 \mathrm{~d}$ & $17,73 \mathrm{~b}$ \\
\hline \hline
\end{tabular}

Keterangan : Nilai rata-rata perlakuan yang ditandai huruf yang sama pada kolom yang sama menunjukkan tidak berbeda nyata menurut Metode Analisis Scott-Knott pada taraf $5 \%$.

Jumlah biji per tanaman, juga sangat ditentukan oleh jumlah polong isi per tanaman. Umumnya, meningkatnya jumlah polong isi akan meningkatkan hasil tanaman. Hal ini sangat terkait dengan aktivitas fotosintesis dan aliran fotosintat ke polong untuk pengisian biji. Biji merupakan sisa asimilat yang ditranslokasikan dan digunakan untuk cadangan makanan serta dapat dijadikan sebagai bahan perbanyakan (Gardner, dkk. 1991).

Perlakuan D, G, J dan K menghasilkan jumlah biji per tanaman yang lebih rendah. Pada perlakuan D, G, dan J sistem olah tanahnya adalah tanpa olah tanah sehingga proses penyerapan air menjadi terhambat. Menurut Sumarno (1987), pengolahan tanah yang baik sangat diperlukan oleh tanaman kacang tanah, dimana dapat menciptakan struktur, aerasi dan drainase yang baik akan mempermudah ginofor masuk ke dalam tanah, sehingga jumlah biji yang dihasilkan lebih banyak.

Pupuk pelengkap cair dan sistem olah tanah berpengaruh terhadap jumlah polong isi per tanaman. Tabel 3, menunjukkan bahwa perlakuan $\mathrm{C}, \mathrm{N}, \mathrm{O}, \mathrm{Q}$ dan $\mathrm{R}$ berbeda dengan perlakuan lainnya yaitu menghasilkan jumlah polong isi pertanaman lebih banyak.
Hal ini terjadi karena dengan dilakukannya pengolahan tanah dapat mempermudah penyerapan hara dan air yang dibutuhkan tanaman pada proses pembentukan biji, dimana kondisi tanah yang baik sangat menentukan terhadap hasil. Menurut Saifuddin sarief (1993), bahwa pengolahan tanah bertujuan untuk memperbaiki struktur dan aerasi tanah agar pengisapan zat hara oleh tanaman dapat berlangsung dengan baik, namun dari hasil penelitian ini pengolahan tanah minimum pun dapat menghasilkan jumlah polong isi per tanaman yang tinggi jika diimbangi dengan pemberian pupuk yang memadai, hal ini terbukti pada perlakuan $\mathrm{O}$ dan $\mathrm{Q}$.

Dosis pupuk pelengkap cair yang diberikan sebesar 4 dan 5 1/ha PPC disertai dengan pengolahan tanah secara sempurna dan minimum dapat meningkatkan jumlah polong isi per tanaman. Banyaknya jumlah polong isi menunjukkan bahwa translokasi fotosintat untuk pembentukan polong dan biji berjalan sempurna. Besarnya fotosintat sangat dipengaruhi oleh proses metabolisme yang melibatkan semua unsur hara yang dibutuhkan (Pessarakli, 1995).

Perlakuan A, B, D, E, F, G, H, I, J, K, L, M dan $P$ memberikan jumlah polong isi per tanaman lebih rendah. Hal mi terjadi karena pada perlakuan $D, E, F, G, H, I, J, K$ dan $L$ diduga penambahan unsur hara melalui perlakuan PPC kurang mencukupi kebutuhan tanaman kacang tanah, sedangkan pada perlakuan $\mathrm{A}, \mathrm{B}, \mathrm{M}$ dan $\mathrm{P}$ diduga walaupun unsur hara yang ditambahkan cukup banyak, tetapi kondisi tanah yang tidak terolah secara sempurna menyebabkan struktur tanah menjadi padat sehingga air yang dibutuhkan pada proses fotosintesis tidak dapat diserap secara optimal oleh tanaman. Hal ini akan menghambat proses translokasi fotosintat untuk pembentukan biji.

Jumlah Polong Hampa per Tanaman dan Jumlah Ginofor per Tanaman. Pupuk pelengkap cair dan sistem olah tanah tidak memberikan pengaruh terhadap jumlah polong hampa per tanaman (Tabel 4). Kurangnya fotosintat umtuk pembentukan biji menyebabkan banyaknya jumlah polong hampa yang dihasilkan oleh tanaman, hal ini sangat berkaitan dengan ketersediaan air, nutrisi yang berguna serta sinar matahari. Adanya suatu unsur hara yang berlebih dapat menyebabkan defisiensi unsur hara lain sehingga menghambat laju fotosintesis (Gardner, dkk. 1991). 
Pupuk pelengkap cair dan sistem olah tanah tidak memberikan pengaruh terhadap jumlah ginofor (Tabel 4). Hal ini disebabkan tekstur tanah pada lahan percobaan adalah tekstur liat berdebu dimana kandungan liatnya tinggi, menyebabkan sulitnya ginofor menembus ke dalam. Kacang tanah akan tumbuh baik bila ditanam pada tanah ringan (loamy sandy) yang cukup mengandung unsur hara, sehingga mempermudah masuknya ginofor ke dalam tanah (Sutarto dkk., 1988).

Tabel 4. Pengaruh Pupuk Pelengkap Cair dan Sistem Olah Tanah Terhadap Jumlah Polong Hampa per Tanaman dan Jumlah Ginofor per Tanaman.

\begin{tabular}{ccc}
\hline \hline Perlakuan & $\begin{array}{c}\text { Jumlah Polong } \\
\text { Hampa per } \\
\text { Tanaman }\end{array}$ & $\begin{array}{c}\text { Jumlah Ginofor } \\
\text { per Tanaman }\end{array}$ \\
\hline A & $1,87 \mathrm{a}$ & $1,44 \mathrm{a}$ \\
$\mathrm{B}$ & $2,15 \mathrm{a}$ & $2,40 \mathrm{a}$ \\
$\mathrm{C}$ & $2,33 \mathrm{a}$ & $3,31 \mathrm{a}$ \\
$\mathrm{D}$ & $2,27 \mathrm{a}$ & $1,76 \mathrm{a}$ \\
E & $2,23 \mathrm{a}$ & $0,99 \mathrm{a}$ \\
F & $2,46 \mathrm{a}$ & $1,55 \mathrm{a}$ \\
$\mathrm{G}$ & $2,35 \mathrm{a}$ & $2,76 \mathrm{a}$ \\
$\mathrm{H}$ & $1,77 \mathrm{a}$ & $2,22 \mathrm{a}$ \\
$\mathrm{I}$ & $3,24 \mathrm{a}$ & $2,34 \mathrm{a}$ \\
J & $2,32 \mathrm{a}$ & $2,22 \mathrm{a}$ \\
K & $1,79 \mathrm{a}$ & $2,37 \mathrm{a}$ \\
$\mathrm{L}$ & $3,15 \mathrm{a}$ & $2,87 \mathrm{a}$ \\
$\mathrm{M}$ & $1,74 \mathrm{a}$ & $2,36 \mathrm{a}$ \\
$\mathrm{N}$ & $2,36 \mathrm{a}$ & $3,22 \mathrm{a}$ \\
O & $2,69 \mathrm{a}$ & $2,16 \mathrm{a}$ \\
P & $2,44 \mathrm{a}$ & $2,23 \mathrm{a}$ \\
Q & $2,33 \mathrm{a}$ & $3,31 \mathrm{a}$ \\
R & $2,22 \mathrm{a}$ & $3,34 \mathrm{a}$ \\
\hline \hline
\end{tabular}

Keterangan : Nilai rata-rata perlakuan yang ditandai huruf yang sama pada kolom yang sama menunjukkan tidak berbeda nyata menurut Metode Analisis Scott-Knott pada taraf $5 \%$.

Bobot 100 butir, Bobot Biji per Tanaman dan Bobot Biji per Petak. Hasil analisis data (Tabel 5), pupuk pelengkap cair dan sistem olah tanah berpengaruh terhadap bobot 100 biji. Perlakuan C, O, Q dan R berbeda dengan perlakuan lainnya yaitu memberikan bobot 100 biji yang terberat.

Pengolahan tanah juga sangat menentukan, yang mana dengan pengolahan tanah dapat mempengaruhi dalam proses pemasukan ginofor ke dalam tanah, sehingga ginofor mudah masuk ke dalam tanah dan membentuk polong dengan sempurna. Selain itu, didukung oleh potensi ukuran biji yang mempengaruhi terha- dap hasil, juga secara langsung ditentukan oleh proses translokasi fotosintat dari daun selama proses pengisian biji.

Ukuran biji tergantung pada kultivar kacang tanah karena secara langsung ditentukan oleh sifat genetik. Proses translokasi fotosintat dari daun selama proses pengisian biji tergantung fotosintat yang ada dan faktor-faktor yang berpengaruh terhadap proses tersebut (Salisbury dan Ross, 1995).

Perlakuan A, B, D, E, F, G, H, I, J, K, L, M, $\mathrm{N}$ dan $\mathrm{P}$ memberikan bobot 100 biji lebih rendah. Hal ini terjadi karena pada perlakuan $D$, E, F, G, H, I, J, K dan L unsur hara yang tersedia tidak mencukupi, sedangkan pada perlakuan $\mathrm{A}$, B, M, N dan P diduga walaupun unsur hara yang ditambahkan cukup banyak, tetapi kondisi tanah yang tidak terolah secara sempurna menyebabkan struktur tanah menjadi padat sehingga perkembangan biji kurang optimal.

Tabel 5. Pengaruh Pupuk Pelengkap Cair dan Sistem Olah Tanah Terhadap Bobot 100 butir, Bobot Biji per Tanaman dan Bobot Biji per Petak.

\begin{tabular}{cccc}
\hline \hline Perlakuan & $\begin{array}{c}\text { Bobot 100 } \\
\text { butir }(\mathrm{g})\end{array}$ & $\begin{array}{c}\text { Bobot Biji } \\
\text { per } \\
\text { Tanaman }(\mathrm{g})\end{array}$ & $\begin{array}{c}\text { Bobot Biji } \\
\text { per Petak } \\
(\mathrm{kg})\end{array}$ \\
\hline $\mathrm{A}$ & $34,29 \mathrm{a}$ & $5,72 \mathrm{a}$ & $0,56 \mathrm{a}$ \\
$\mathrm{B}$ & $34,39 \mathrm{a}$ & $6,23 \mathrm{a}$ & $0,62 \mathrm{a}$ \\
$\mathrm{C}$ & $44,59 \mathrm{~b}$ & $9,05 \mathrm{c}$ & $0,90 \mathrm{~b}$ \\
$\mathrm{D}$ & $35,25 \mathrm{a}$ & $5,47 \mathrm{a}$ & $0,55 \mathrm{a}$ \\
$\mathrm{E}$ & $33,37 \mathrm{a}$ & $6,49 \mathrm{a}$ & $0,64 \mathrm{a}$ \\
$\mathrm{F}$ & $35,12 \mathrm{a}$ & $7,54 \mathrm{~b}$ & $0,64 \mathrm{a}$ \\
$\mathrm{G}$ & $32,55 \mathrm{a}$ & $4,67 \mathrm{a}$ & $0,49 \mathrm{a}$ \\
$\mathrm{H}$ & $33,69 \mathrm{a}$ & $5,54 \mathrm{a}$ & $0,54 \mathrm{a}$ \\
$\mathrm{I}$ & $34,25 \mathrm{a}$ & $6,22 \mathrm{a}$ & $0,62 \mathrm{a}$ \\
$\mathrm{J}$ & $32,45 \mathrm{a}$ & $5,24 \mathrm{a}$ & $0,54 \mathrm{a}$ \\
$\mathrm{K}$ & $34,58 \mathrm{a}$ & $6,76 \mathrm{a}$ & $0,67 \mathrm{a}$ \\
$\mathrm{L}$ & $37,26 \mathrm{a}$ & $8,14 \mathrm{~b}$ & $0,66 \mathrm{a}$ \\
$\mathrm{M}$ & $34,10 \mathrm{a}$ & $6,43 \mathrm{a}$ & $0,63 \mathrm{a}$ \\
$\mathrm{N}$ & $35,26 \mathrm{a}$ & $6,75 \mathrm{a}$ & $0,65 \mathrm{a}$ \\
O & $42,77 \mathrm{~b}$ & $7,62 \mathrm{~b}$ & $0,67 \mathrm{a}$ \\
P & $34,38 \mathrm{a}$ & $5,74 \mathrm{a}$ & $0,57 \mathrm{a}$ \\
Q & $43,47 \mathrm{~b}$ & $8,82 \mathrm{c}$ & $0,88 \mathrm{~b}$ \\
R & $44,25 \mathrm{~b}$ & $9,01 \mathrm{c}$ & $0,93 \mathrm{~b}$ \\
\hline \hline
\end{tabular}

Keterangan : Nilai rata-rata perlakuan yang ditandai huruf yang sama pada kolom yang sama menunjukkan tidak berbeda nyata menurut Metode Analisis Scott-Knott pada taraf $5 \%$.

Pada Tabel 5, dosis pupuk pelengkap cair dan sistem olah tanah berpengaruh terhadap bobot biji per tanaman. Perlakuan C, Q dan R berbeda dengan perlakuan lainnya yaitu memiliki bobot biji per tanaman terberat.

Tersedianya nutrisi yang dibutuhkan oleh tanaman yakni hara makro dan mikro sangat 
berperan dalam mendukung metabolisme, salah satunya untuk membentuk biji yang sempurna. Menurut Sumarno (1987), dengan terciptanya keseimbangan unsur hara yang dibutuhkan tanaman dalam proses pembentukan biji akan meningkatkan hasil.

Pengolahan tanah sempurna dan minimum mempengaruhi terhadap hasil tanaman dimana pengolahan tanah dapat mempennudah proses penyerapan air yang dibutuhkan tanaman pada proses fotosintesis. Fotosintat yang dihasilkan kemudian disalurkan ke berbagai bagian tanaman tennasuk ke bagian biji. Fase pengisian biji pun menjadi lebih optimal dan hal ini berpengaruh terhadap bobot biji yang dihasilkan.

Perlakuan A, B, D, E, G, H, I, J, K, M, N dan $\mathrm{P}$ memberikan bobot biji per tanaman yang lebih rendah. Hal ini disebabkan karena tekstur tanah tergolong liat berdebu, pada perlakuan tanpa olah tanah dan pengolahan tanah minimum tanpa diimbangi hara yang memadai diduga belum cukup untuk memberikan struktur tanah yang optimal, sehingga unsur hara dan air tidak diserap tanaman akhirnya akan mempengaruhi terhadap bobot biji per tanaman.

Pada Tabel 5, pupuk pelengkap cair dan sistem olah tanah berpengaruh terhadap bobot biji per petak. Perlakuan C, Q dan R berbeda dengan perlakuan lainnya yaitu memiliki bobot biji per petak dan bobot biji per hektar terbesar.Hal ini terjadi karena kebutuhan unsur hara makro maupun mikro tercukupi. Unsur hara makro dan mikro tersebut dibutuhkan pada proses pertumbuhan dan pembentukan biji. Proses pertumbuhan dan pembentukan biji ini sangat menentukan hasil produksi.

Selain itu sistem olah tanah yang dilakukan pada perlakuan ini sangat mendukung. Hal ini terjadi karena pengolahan tanah menciptakan struktur tanah yang gembur, aerasi dan drainase yang baik sehingga proses pemasukan ginofor untuk menjadi polong yang selanjutnya terjadi proses pembentukan biji menjadi lebih baik.

Perlakuan A, B, D, E, F, G, H, I, J, K, L, M, $\mathrm{N}$, O dan $\mathrm{P}$ memberikan bobot biji per petak lebih rendah. Hal ini disebabkan karena tekstur tanah tergolong liat berdebu. Sifat utama tanah liat berdebu adalah secara umum unsur hara yang terkandung di dalam tanah tergolong rendah (Saifuddin Sarief, 1993), sehingga kurangnya unsur hara yang diserap oleh tanaman kacang tanah pada waktu pembentukan polong menyebabkan rata-rata bobot biji per petak menjadi rendah. Hal ini diperparah dengan sistem olah tanah yang kurang serta pemupukan yang rendah. Bobot biji per petak tertinggi pada percobaan ini adalah 0,93 $\mathrm{kg}$ setara dengan 1,31 ton/ha. Rata-rata bobot biji per ha pada percobaan ini masih belum optimal jika dibandingkan dengan deskripsi, yaitu 1,00 - 4,00 ton/ha. Hal ini kemungkinan disebabkan oleh adanya batasan-batasan tersebut diatas, maka pembentukan dan pengisian biji terganggu dan mengakibatkan bobot biji akan berkurang dan secara langsung akan berpengaruh pada bobot biji/petak dan bobot biji/ha.

\section{Kesimpulan dan Saran}

Berdasarkan hasil percobaan dapat disimpulkan sebagai berikut:

1. Perlakuan pupuk pelengkap cair (PPC) dan sistem olah tanah memberikan pengaruh terhadap indeks luas daun, bobot kering tanaman, jumlah biji per tanaman, jumlah polong isi per tanaman, bobot 100 biji, bobot biji per tanaman dan bobot biji per petak.

2. Perlakuan $5 \mathrm{~L} /$ ha $\mathrm{PPC}+$ Pengolahan tanah minimum memberikan pengaruh terhadap indeks luas daun, bobot kering tanaman, jumlah biji per tanaman, jumlah polong isi per tanaman, bobot 100 biji, bobot biji per tanaman, dan bobot biji per petak dibanding dengan perlakuan yang menggunakan pupuk organik cair dan tidak berbeda dengan perlakuan kontrol $50 \mathrm{~kg} / \mathrm{ha}$ Urea $+125 \mathrm{~kg} / \mathrm{ha}$ $\mathrm{SP}-36$ + $100 \mathrm{~kg} / \mathrm{ha} \mathrm{KC1}+$ pengolahan tanah sempurna dan $5 \mathrm{~L} /$ ha $\mathrm{PPC}+$ pengolahan tanah sempurna

Saran pada percobaan ini adalah penggunaan pupuk pelengkap cair perlu diteliti lebih lanjut melalui penelitian dengan perlakuan yang sama dengan aplikasi melalui daun dari 2 MST sampai dengan 6 MST.

\section{Ucapan Terima Kasih}

1. Kepala Kebun dan Rumah Kaca Fakultas Pertanian Universitas Padjadjaran.

2. Fakultas Pertanian Universitas Padjadjaran.

3. Mahasiswa Peminatan Pangan Departemen Budidaya Pertanian Fakultas Pertanian Universitas Padjadjaran.

\section{Daftar Pustaka}

Agustina, L. 1990. Nutrisi Tanaman. Penerbit Rineka Cipta. Jakarta. 
Badan Pusat Statistika. 2016. Statistika Indonesia. Jakarta. https://www.bps.go.id/linkTable Dinamis/view/id/875

Gardner F. P., Pearch B. R., dan Mitchell. 1991. Fisiologi Tanaman Budidaya. Terjemahan. Herawati Susilo. UI Press. Jakarta.

Kasno, A., A. Winarto dan Sunardi. 1993. Kacang Tanah. Departemen Pertanian BPPP - BPPT Pangan Malang,

Leiwabessy. 1982. Bahan Kuliah Kesuburan Tanah. Jurusan Tanah Fakultas Pertanian IPB. Bogor (Tidak dipublikasikan).

Manwan, I., Sumarno, A. Syarifuddin dan A. M. Fagi. 1990. Teknologi Peningkatan Produksi Kedelai di Indonesia. Puslitbangtan, Bogor.

Pessarakli, M. 1995. Physiological Responses of Cotton (Gossypium hirutum L.) to Salt Stress. P. 679-694. hi. M. Pessarakli (Ed.). Handbook or Plant and Crop Physiology. Marcel Dekker, Inc. New York.
Poehlman, J. M. 1991. The Mungbean. Oxford and IBH Publishing Company. New Delhi.

Sarief, S. 1993. Ilmu Tanah Pertanian. Pustaka Buana. Bandung.

Saleh. 1979. Percobaan Pendahuluan Pemupukan Lewat Daun Pada Tanaman Kopi. Menara Perkebunan. Vol. 2 Hlm. 22 - 27.

Salisbury dan Ross. 1995. Fisiologi Tumbuhan III. Perkembangan Tumbuhan dan Fisiologi Lingkungan. (Terjemahan Diah R. Lukmana dan Sumaryono). ITB. Bandung.

Sinukaban, N. 1981. Pengolahan Tanah Konservasi Pada Pertanian Tanaman Padi dan Jagung. Risalah hasil penelitian tanaman pangan. Balai Penelitian Tanaman Pangan. Bogor.

Haryadi, S.S. 1989. Pengantar Agronomi. Gramedia. Jakarta.

Sumarno. 1987. Teknik Budidaya Kacang Tanah. Sinar Baru. Bandung.

Sutarto, I.V., Harnoto, dan S.A. Rais. 1988. Kacang Tanah. Puslitbangtan. Bogor. 